\title{
MUSIC AND TRADITIONS OF THRACE (GREECE): A TRANS-CULTURAL TEACHING TOOL ${ }^{1}$
}

\author{
Kalliopi Stiga ${ }^{2}$ \\ Evangelia Kopsalidou ${ }^{3}$
}

\begin{abstract}
The geopolitical location as well as the historical itinerary of Greece into time turned the country into a meeting place of the European, the Northern African and the Middle-Eastern cultures. Fables, beliefs and religious ceremonies, linguistic elements, traditional dances and music of different regions of Hellenic space testify this cultural convergence. One of these regions is Thrace. The aim of this paper is firstly, to deal with the music and the dances of Thrace and to highlight through them both the Balkan and the middle-eastern influence. Secondly, through a listing of music lessons that we have realized over the last years, in schools and universities of modern Thrace, we are going to prove if music is or not a useful communication tool - an international language - for pupils and students in Thrace. Finally, we will study the influence of these different "traditions" on pupils and students' behavior.
\end{abstract}

Key words: Thrace; music; dances; multi-cultural influence; national identity; trans-cultural teaching

Resumo: A localização geopolítica, bem como o itinerário histórico da Grécia através do tempo, transformou o país num lugar de encontro das culturas europeias, norte-africanas e do Médio Oriente. Fábulas, crenças e cerimónias religiosas, elementos linguísticos, danças tradicionais e a música das diferentes regiões do espaço helénico são testemunho desta convergência cultural. Uma destas regiões é a Trácia. O objectivo deste artigo é, em primeiro lugar, tratar da música e das danças da Trácia e destacar através delas as influências tanto dos Balcãs como do Médio Oriente. Em segundo lugar, através de uma exposição de aulas de música realizadas nos últimos anos, em escolas e universidades da Trácia moderna, iremos averiguar se a música é ou não um instrumento útil de comunicação - uma língua internacional - para alunos da Trácia. Por último, estudaremos a influência destas diferentes "tradições" sobre o comportamento de alunos.

Palavras-chave: Trácia; música; danças; influência multi-cultural; identidade nacional; ensino transcultural

\section{A history of Thrace}

The geopolitical location, as well as the Greek history into time turned the country into a meeting point of the European, the Northern African and the Middle-Eastern cultures. Fables, beliefs

Stiga, K.; Kopsalidou, E. (2012). Music and traditions of Thrace (Greece): a trans-cultural teaching tool. DEDiCA. REVISTA DE EDUCAÇÃO E HUMANIDADES, 3 (2012) março, 145-164 
and religious ceremonies, linguistic elements, traditional dances and music of different regions of the Hellenic area testify this cultural convergence. One of these regions is Thrace, which extends to the north-eastern part of the country and borders on Bulgaria in the North and Turkey in the East.

"Thrace was the homeland of Orpheus, priest, seer and father of the bards. According to the tradition, Orpheus, the son of Apollo (or in another version, the son of the Thracian King Oiagros) and the Muse Calliope instituted the Orphic Mysteries and all rituals associated with them. There, seated on the bank of the River Evros, according to Aristophanes, the initiated paved the way for the brilliant course traced by this region over the centuries. This was a land of mysterious rites, where apart from the Orphic Mysteries, the worship of god Bacchus or Dionysus and the worship of the Cabeiri on the island of Samothrace were flourishing. Orpheus descended to Hades to rescue his beloved wife Eurydice from the Dead. But he lost her forever and in the end, he was lost as well, holding his lyre in the dark waters of the River Evros; he was one more victim of the wrath of the Maenads" (Doukas, 1996: 33).

The region of Thrace with its coastline in the Aegean Sea, with the Mountain of Rodopi and with the Rivers Nestos and Evros, is a province of contemporary Greece, but it was a small corner of the ancient land, which stretched from the Aegean Sea and the Hellespont to the Danube and from the Black Sea to Macedonia. Its geopolitical location between Europe and Asia was a determinant factor in its historic formation. Thrace, more than any other region, has experienced migrations, colonization, hostile invasions, wars and military occupations. At the same time, Thrace was constantly receiving the powerful formative influence of neighboring peoples and cultures (Diamantis, 1996).

The first traces of life in this province, the bones of large animals that had lived there 3 to 5 million years ago, were discovered in the area of Ormenion and Krios, between the Rivers Evros and Ardas. It was during the last decades of the Late Bronze Age (1600-1050 BC) that Thracian tribes settled in southern Thrace throughout the eastern and southern Balkans, both in the Mountains Rodopi and Ismaros. The Thracians and the Greeks shared a common origin and hence, the two peoples followed a parallel history. The links between those two are reflected in the Greek mythology, which includes figures of Thracian origin like Eumolpos, Orpheus, Musaeos, Thamyris and Linos. Some of the legends tell 
the stories of Diomedes, king of the Vistones, Tereas and Prokne, Orpheus and Eurydice, Lykourgos, King of the Hedonoi, Voreas and Oreithyia.

Thracians were divided into numerous autonomous tribes (like the Sapaeans, the Vistones and the Kikones) that may have lived in proximity, but were widely different in character, in social structure and in cultural level. These differences frequently resulted in armed conflicts and population shifts. The entrance of Thracians in the historical scene was actually the result of their Hellenization and of the powerful influence of the Greek spirit. Greek colonists from the eastern Aegean islands and the cities of Asia Minor abandoned their homes, partly for social and political reasons, but mostly in search of new sources of wealth in land and founded cities such as Avdera, Dikaia, Stryme, Maroneia etc. All colonies soon became the centres from which the Greek civilization began to spread further afield, spreading throughout the Thracian territory the language, the religion and the culture of Greeks, and thus initiating the Hellenization of Thracians.

In AD 46, Thrace became a Roman province with its capital at Perinthos. The Roman emperors founded there new cities (Topeiros, Traianopolis, Adrianopolis, etc. and built highways linking the province's main cities with both the Central Europe and the sea. One of these highways was the Via Egnatia, which allowed the safe movement of people, merchandises and military formations from Dyrrhachium to Byzantium. Throughout the period of Roman rule, the Hellenization of Thracians continued. The use of the Greek language was universal. Almost all the inscriptions that have been discovered from the Aegean Sea to the Danube are in Greek with only a very few of them in the official Latin language of the Roman Empire (Triantaphyllos, 1996).

The opening of the Via Egnatia and the other highways through Thrace and the foundation of the city of Constantinople (330) in the southeastern corner were the two facts that had a profound impact not only in the immediate area, but also throughout the entire Empire. Lying between Constantinople and Thessaloniki, Thrace was to play an important role in the thousand year old history of Byzantium and to serve as a northern bulwark against successive waves of hostile raids (Visigoths, Huns, Avars, Crusaders, Bulgarians, Catalans and Ottoman Turks). The numerous ancient Greek, Roman and Byzantine cities founded along its shores and scattered through its interior, show the importance of this area 
across the centuries, an area which maintained its geographical unity until the end of the $19^{\text {th }}$ century.

The civil wars and dynastic battles of the $14^{\text {th }}$ century (1321$1328,1341-1347 / 54)$ gave to the Ottoman Turks the opportunity to step in. Major cities fell the one after the other to Ottoman hands. Isolated and denuded of its power, Constantinople could not stave off defeat any longer and was conquered in 1453 (Zikos, 1996). The period from the $13^{\text {th }}$ to the $15^{\text {th }}$ century was indeed a watershed in the history of Thrace. Many tragic events left their mark on Thrace and on the entire Hellenic world (the Frankish occupation, the intra Byzantine strife, the Ottoman Turks invasions). The population structure was altered as Turkmen and other population groups from the depths of Asia were brought in to colonize the conquered territories for several centuries. With the fall of Constantinople, the Ottoman control of Thrace was complete. This period marks the beginning of modern Hellenism.

However, despite all objective difficulties, the Greek population managed not only to survive, but also to progress and to become the basic agent of the economic life of the area. The Muslims of Thrace are the descendants of Turkmen settlers and islamized native populations. It is estimated that among the total Muslim population of southwestern Thrace (the present Greek province) there are 50\% Turkish by origin or assimilation, $35 \%$ are Pomaks and 15\% Rom (Mousopoulos, 1996).

During the difficult years of the Ottoman rule, some larger institutions acquired particular significance for the Greeks and played an increasingly important role in their lives. In the meanwhile, Thracian ships were sailing to Odessa, Alexandria, Malta, and Marseilles, mainly from the city of Aenos and Thracian merchants and caravan-traders were crossing in Europe and bringing at home the new ideas generated by the Enlightenment. The $18^{\text {th }}$ and $19^{\text {th }}$ centuries were Thrace's Renaissance and were accompanied by a growing hunger for liberty, which has been existed since the $16^{\text {th }}$ century. Songs - 'kleftika' - tell of the Kleftes (armed outlaws), who were ubiquitous in the mountains of Rodopi and in other isolated areas of the Thracian hinterland showed this spirit. The forth of the Friends of the revolutionary organization known as the Philiki Etairia (Society of Friends) founded in the $19^{\text {th }}$ century was a Thracian and revolutionary movement organized in Thrace.

Popular culture, which continued to survive, kept alive the link between modern Thrace and its ancient Greek past. Musical 
instruments, melodies, songs and dances, fairs and festivals, all continued to entertain the sons and daughters of Thrace.

In the meanwhile, by mid- $19^{\text {th }}$ century, Thrace became a field for competing national claims. Northern Thrace proclaimed an autonomous province under the name Eastern Rumelia in 1878; it was annexed by Bulgaria in 1886 and its Greek inhabitants were massacred, exiled or some of them went back to Greece as refugees. In 1919-1920, southwestern Thrace (that is nowadays the prefectures of Xanthi, Rodopi and Evros), which six years earlier in 1913, had been ceded by the Great Powers to Bulgaria, reunited with Greece after 560 years under the Ottoman rule. "Eastern Thrace, which was also granted to Greece in 1920, was ceded to Turkey in 1922-1923 after the military defeat of Greece in Asia Minor. With the compulsory exchange of populations, hundreds of thousands of Greeks were forced to abandon their homes in the eastern sector and seek refuge in southwestern Thrace and elsewhere in Greece. From this forcible exchanges of population were exempted the Orthodox Greeks of Constantinople and of the Thracian island of Imvros and Tenedos, as well as the Muslims of the southwestern Thrace. But during the decades that followed, the Greeks remaining in Constantinople and the Islands of Imvros and Tenedos were also forced, in one way or another, to leave their homes, so that today there are no more than 2000 persons left" (Mousopoulos, 1996: 30).

The influx of refugees from northern and eastern Thrace and Asia Minor in the 1920's fortified the local population with groups of men and women with a rich and varied Greek heritage. We have to add to these refugees, the ones coming after the Bulgarian occupation during the World War II.

"Traditional culture is presented and promoted at every opportunity: dances, customs, popular Greek art and traditions from all over Thrace - northern, eastern and southwestern Thrace- from Asia Minor, the Black Sea provinces, Cappadocia, as well as the traditional culture of the Armenians, the Pomak people and the Rom. The mixture is further enriched with Greeks whose origins are from other regions - Macedonia, Epirus, Thessaly, Crete or Cyprus. And if we add to this mosaic, the more recent Greek immigrants from the countries of the former Soviet Union and the Balkan states, then Thrace can certainly be seen as a privileged meeting point of peoples and cultures, a place where all the Balkan cultures mostly live side by side" (Mousopoulos, 1996: 30-31). 
The uniqueness of this region, lying in the transitional zone where Asia and Europe geographically and culturally fade one into the other, is mainly the product of the parallel presence of Christianity and Islam. This region is like a home to an extraordinary diversity of traditions, which could be described as a "living cultural mosaic". The sharp contrasts not only in the religious field, but also among different population groups are reflected throughout their material and their verbal expression. Traditional customs, which are still in use in some parts of the prefecture, define cultural boundaries, but also reveal the mutual influences of various population groups to one another. The wealth of traditional songs, religious festivals and dances generally performed to the accompaniment of bagpipes is truly astounding, while the melodic lines of the sedentary songs (sung around the table / kathistika) of eastern Thrace still follow the ancient traditions of Byzantine ecclesiastical music (Liapis, 1996).

The presence of Army Corps and the numerous Faculties of the Democritus University of Thrace mean a considerable youthful presence in the city life with positive impacts on its social and cultural development. Local writers, painters, musicians and scientists live there. Magazines, books and newspapers, radio and television stations cover and feature local events with considerable success (Mousopoulos, 1996).

\section{Music, Dances and Traditions of Thrace}

The study of Thracian music, singing and dancing, as well as their interpretative approach form part of the highly ambitious research project "Listing, Study and promotion of Greek traditional music", which started in 1995, is sponsored by the Association "Friends of Music" and involves prominent Greek scientists (historians, ethnomusicologists, musicologists, anthropologists, etc.). It is obvious that in this article, whose objective is not a detailed presentation of the music, of the dances and of the traditions of Thrace, but of the designation of their utility as an educational tool, we will restrict ourselves to a brief summary thereof.

"The central location of Thrace in the Byzantine Empire, the intellectual and religious radiance of Constantinople and the historical twists in the Thracian area were some of the main factors in the creation of the local folk culture. This civilization is in many forms identified by stuffiness and preservation of elements of antiquity and of the subsequent Byzantine period, at least until the first decades of the twentieth century and particularly until 1923 and 
the signing of the Treaty of Lausanne with the general population and ethnic upheavals in the Balkans" (Encyclopedia Papyros Larousse Britannica, Thrace, vol. 28: 245).

The religious customs and doctrines of the population of Thrace are considered as a representative sample of the oldest layers of the folk culture of the area. Among others, traditional customs with mime performances of fertile character, "nestinarstvo" (fire-dance, N. Thrace), "The Twelve Days of disguise and carnival»" are repeated and adhered to date, accompanied by respective dance acts (Tyrovola, 1998: 100-101).

The music of Thrace presents a great variety in tunes, dances and songs and includes a tuple of melodies - which sometimes reminds of Byzantine hymns-, old acritic and narrative songs, urban folk songs, amanedes (long-drawn out love songs), peppy tunes with purely local color, as well as other tunes which were molded from the relationships and interactions with neighboring regions in Thrace. Unlike the rest of mainland Greece, klephtic songs are missing, as the vicinity to the capital of the Ottoman Empire and the lowland ground did not favor the development of klephts' gangs.

We can distinguish three relative musical idioms, which in some way correspond to the three districts - the East (the area of European Turkey today), the West (geographical division of Greece in the northeastern part of the country) and the North (Eastern Rumelia, territories that now belong to southeastern Bulgaria) - in which it was divided the single area of Thrace in the early last century.

The music of Eastern Thrace, merry and melodious, is particularly influenced by the secular and chanting music life of Constantinople and it is akin to that of Asia Minor and the islands of East Aegean Sea. Thus, the dance songs of Eastern Thrace testify urban origins in melody and rhythm, while the nice, but hard slow sedentary songs with the elaborate melodic line and the ornate trims reveal relations of affinity with the Orthodox Byzantine music tradition and its theoretical system. These songs were composed in Edirne, in Raidestos, in Madytos, in Kırklareli, in Heraclea, Gallipoli, in Vizyi, in Selymbria etc.

The music of Western Thrace has an internal diversity depending on the parts with which it borders, as well as with the different refugee populations that settled in 1922 next to those that already existed. Thus, the western part is correlated to the music of Eastern Macedonia, while across the Aegean coast up to the inland, 
we find in many settlements refugees from different regions - Asia Minor, Cappadocia, Pontiacs, Thracians from Northern and Eastern Thrace and recently Pontiacs from the former Soviet Union - who keep their music specificities. Moreover, there are Sarakatsani, Arvanites, Muslims of Turkish origin, Pomaks, Gypsies, Armenians, Gkagkavouzides and old populations in the wider areas of Didymoteicho, Soufli and Orestiada. In this latter region and especially in the villages along the Erythropotamos River, we can find the most interesting and dynamic populations in terms of music. Their musical idiom is one of a kind all over Greece. There is domination of quick and peppy tunes and dances, along with some slower ones that associate us with the rest of Thrace.

The music of Northern Thrace with its characteristic style was cultivated in urban centers and historic cities - Plovdiv, Stenimacho, Sozopol, Kavakli, Anchialos, Mesimvria, Varna, Pyrgos, lampoli etc. and in remote villages in the mountains with dense forests, in Rhodope and in Small Haemus-Strantza. However, we detect several music similarities in the continental part of Northern Thrace with the part of Western Thrace, while in the Thracian coast of the Black Sea the music is closest to that of Eastern Thrace.

More specifically, the affinity of Thracian music with that of neighboring areas is identified in the melodic material, in the rhythmic patterns and in used musical instruments.

It is worth mentioning that the melodies are mostly modal, proving that the folk music of Thrace has also its roots in Byzantine music. However, strong is the influence from Arabic and Turkish music, as it is frequent the use of tetrachords and makam of eastern origin, such as Kiournti (song: "Pearl Pot"), Samba (song: "Manliness is for once"), Chouzam (song: "Put those in your hands"), Segkiach (song: "When you gave me birth, Mother?"), Bestenigkiar (song: "Give me your hand, Mother"), Segkiach (song: "When you gave me birth, Mother?") ${ }^{4}$ (Mavroeidis, 1994).

As far as the rhythms are concerned, Thrace is one of the most prosperous areas in Greece as a whole. Apart from the slow sedentary songs in free rhythm, one encounters a variety of simple and complex rhythms - from two-beat to twelve-beat - and even in different versions. These rhythms correspond to a wide variety of dances. The main ones are the followings: zonaradikos, the two wedding dances, mantilatos, sygkathistos, baintouska and syrtos sygkathistos that are particular in western and continental regions of Thrace. There is total dissemination of different forms of syrtos 
dance and chasapikos dance - a dance from Constantinople - which are danced mostly in the eastern region of Thrace, along with karsilamas dance. Along them, a number of customary and other dances of minor proliferation complete the dance diversity of Thrace. Several times, the same tune is danced differently by women and men and dances from the rest of Greece get local color and are adapted to the local dances (Dionysopoulos, 1994: 10-22).

Briefly, we mention that:

- dances of eastern Thrace are characterized by common music-dance types with those from the coasts of Asia Minor. Predominant rhythms are two-beat and four-beat.

- dances of western Thrace barely resemble to dances from other Greek areas, as the special melodic lines, the kinesiological content and the intense rhythmic manner mould a local idiom. The main dance rhythmic patterns are those of two-beat, three-beat, fourbeat, five-beat, six-beat, seven-beat and nine-beat rhythm.

- dances of northern Thrace are similar to the dances of western Thrace, even though they follow a more complex movement and faster rhythmic patterns. Their special feature is the concept of 'polyrhythm', where the movements of the hands, of the torso and of the legs obey at different rhythms at the same time of the performance. The two-beat, four-beat and seven-beat rhythms dominate (Tyrovola, 1998:101-103).

The dances zonaradikos or zounaradikos or znaradikos and mantilatos are of particular interest.

The "Zonaradikos" dance is also mentioned as "panthrakikos dance", as it is danced throughout Thrace with many variations from one region to another. It owes its name to the hold of hands from the "belts" (= zoni). This is a circular dance of mixed nature - it is danced both by men and women - and quick, hopping steps with vibrancy. Usually, the melodies of "zonaradikos" dance have quick rhythmic action, but there are also tunes that are performed slower. The music measure is usually $2 / 4,4 / 4$ or $6 / 8(3 / 8+3 / 8)$ and it is considered as the basic rhythm of 'zonaradikos' dance (Lykesas, 1993: 141-142).

The "Mantilatos" dance, whose name derives from the headscarves that the dancers hold on the left or on the right hand or with both hands, is a 'sygkathistos' dance. It is always danced face to face, either by people of the same sex or by the opposite one, either in straight line or in a circular manner. The rhythm of "mantilatos" dance is seven-beat $7 / 8(4+3=7)$. There are either dancing 
melodies in lively rhythm or they have lyrics (songs) and are slightly slower (Lykesas, 1993: 146).

Finally, it is observed a large variety of used traditional musical instruments. Previously, the area was dominated by bagpipes (askavlos), the crotch (long wooden flute) and the two musical instruments of fire-dancers (nestinari): the old pear-shaped lyre and the tabor and they were often collaborating with the bagpipes. It is stated that in the region of Orestiada, carols were accompanied by daireh (large tambourine) and masies (drums percussion instruments with cymbals), while in the area of Komotini and Didymoteicho we can find the well known zigia of continental Greece, the zourna-tabor. Nowadays, there is more and more often the "troupe" in festivities and celebrations, which consists of the clarinet or the flute, the violin, the oud and the kickback (toumpeleki). In the interwar period, it was primarily the violin with the oud or the tsimpisi (an instrument similar to banjo), and from pictures of this period, we realize the presence of santurs, kornetas and clarinets among the urban populations in eastern Thrace. In the postwar period appear occasionally the lute and more often the accordion, as musical instruments of Thracian bands.

The music of Thrace remained unknown in all over Greece until the early '50s. The first song recording was in 1953. The current composition of the local orchestra was greatly influenced by the recordings and the radio (Dionysopoulos, 1994:10-22).

\section{Music lessons in multicultural classrooms}

The minority of Greek Muslim citizens of Turkish origin and the influx of immigrants mainly from the former Soviet Union and Bulgaria at the geopolitical part of Thrace that belongs to Greece make it necessary to apply cross-cultural programs in our schools and therefore to apply music programs of intercultural perspective, considering the multicultural composition of our school classes, but also the existing racist beliefs in society.

Having been teaching at all levels of Education over the last fourteen years and in the region of Thrace over the last decade, we have been using several methods and models of intercultural music education that promote the element of humanity, enhancing the skills and the self esteem of culturally diverse students, recognizing their diversity and integrating them in the wider educational and social group. These teaching models are based on common or not musical elements of cultures from a different origin. 
The applied models of intercultural music education, promote the element of humanity, while considering the music according to its socio-cultural frame of reference without neglecting the music learning itself; it is the model of dynamic multiculturalism of Elliot, the cross-cultural model of Nketia and the "ethno musicological" humanitarian model of Drummond.

Our core teaching approaches are the approach through the "musical concepts", the approach of "different types of musical instruments", the approach by teaching "songs with a specific topic", "the "guided listening", "song performances" by students , "the celebrations" and "the cultural or integrated study" (Sakellaridis, 2010: 30-33).

According to the above mentioned, we avoid highlighting ethnicity and differences in national cultures on our teaching, whereas we show the music and the cultural diversity of each student, regardless of the place or the country of origin or the cultural unity to which he or she belongs. We use different perspectives of intercultural music awareness, combining the relativistic and comparative philosophy rather than applying a one-dimensional relativistic mode of action or a comparative process. We help to understand the music of all different cultural students, reinforcing it with elements from other frames of concern, such as social, historical, cultural, the field of traditional customs, etc. We do not take the view that a musical culture is superior to others, even if we urge students to adopt a critical attitude. In other words, we cultivate skills of empathy, of tolerance of contradictions, of critical attitude and of communication-exchange. We apply the principles of intercultural education. At every opportunity, we apply the interdisciplinary teaching method by linking music with other activities and school subjects, with a view not only to the cognitive, but also to the emotional development of students, satisfying the expressive, the emotional, the psychological and the social needs. We adopt and include basic principles of creative teaching in order to foster creativity in children (Sakellaridis, 2010: 34-36).

In this way, we deepen in "our" music tradition, we recognize it, we perceive it and we accept it in order to understand the music culture of the others and the "Other" as a particular personality.

The material and the means used each time are adapted to the dynamics of the group of pupils and students. The basic repertoire of songs remains more or less fixed at students' environment, focusing on songs from Thrace and Turkey, Bulgaria, 
former Soviet Union, Armenia and occasionally from Spain and Cyprus. The main body of songs is composed by: "Love is a pin", "I was fooled by birds", "Dance with kerchiefs" (=mantilatos), "Romiopoula's", "Vasilikouda", "Pirpirouna", "Sygkathistos" (Thrace), "Yuksek yuksek tepelere ev kurmasinlar", "Yeni Yil, Sevgiye Cagri" (Turkey), "Zvika Zviri" (Pomak), "Guveyi trasi" (Rom), "Elenke" (Bulgaria), "Kalinka" (former Soviet Union), "Sevach Tsiroum Ness" (Armenia), "Foum-foum", "Los Peces en el Rio", "El Tambolirelo" (Spain), "Cypriot Carols" (Cyprus).

Apart from singing, we use the active music listening, the manufacture of makeshift musical instruments, the performance of children or of their family members on musical instruments in the classroom, improvisation, reading and writing and various creative music activities.

We focus on the active listening of music and on the performance of the songs mentioned above, as well as on the music that mainly concerns dances from Thrace, mentioned on the second part. Usually, a native speaker (pupil or student) helps us to understand and pronounce in a better way the language or the idiom of a song. Sometimes, we make drawings inspired by the lyrics of a song or we even use the lyrics to dramatize a song. We always dance the song (if possible), analyzing in a better way the type of the dance and of the rhythm. We often use the lyrics to emphasize on other customs.

If a pupil or a student happens to play one of the traditional musical instruments, we also perform the songs in this way. Most of the times, we adjust our performances to the musical instruments that we have in the classroom (percussions, piano, guitar, violin, etc.). We often invite musicians, who are usually pupils' family members or friends, specialized on traditional music to perform for us the above mentioned songs and to help us with our performance.

The two indicative teachings that follow were realized the first one at the Fourth Grade of Primary School and the second one at a group of students of the Faculty of Education at the Democritus University of Thrace. 


\section{Lesson Plan 1}

Topic: song "Romiopoula's"

The rhythm of the song is five-beat $(2+3)$ and it is danced in a circular way as baintouska dance. The poetic text consists of decasyllabic iambic verses, with rhyme schemes and "intersection pause" after the fifth syllable, while every musical stanza covers two verses. At the beginning, there is free improvisation with the Thracian lyre, while in the course of the song, the flute, the violin and the bagpipe "converse" with the rest of the orchestra. The melody follows the Re mode, first mode for two voices or naos in Byzantine music. A possible origin could be Rhodes Island, but in Thrace they also identify the place name of the first verse with the known locations of "Rhodope" or the "Valley of Roses". There is evidence that the song is prior to the16th $-17^{\text {th }}$ century. It refers to Romiopoula, who was loved by a Turk man.

Main activity: listening - singing - movement - dancing.

Duration: two teaching hours of 45 minutes.

Objective:

1. To be introduced in the music of Thrace.

2. To learn the melody and the lyrics of the song.

3. To accompany with motion and mimic movements the content of the song.

4. To dance the song (folk dance baintouska).

5. To be introduced to the beat of the measure of $5 / 8$.

Material - Means:

1. Adequate space for movement.

Development:

1. The teacher sings the song with a right voice of good quality, expressiveness and accompanying body movements in the rhythm of $5 / 8$. She asks from students to comment on it (language, topic).

2. Students express their views. The teacher interprets the lyrics. Then follows a discussion and a connection of the 
topic of the song to other school subjects (geography, environmental studies).

3. She repeats the song and students participate wherever is possible. She recites verses rhythmically. Students repeat until they memorize them.

4. The teacher sings the song once more by using hand movements to assist in the proper voice placement. Students sing while they are watching the hand of the teacher and if they want, they can imitate the movements with their hands.

5. Everyone sings the song while standing up in a circle and accompanies it with body mimic movements repeatedly, in order to memorize, while listening to the CD player.

6. Everyone stands up in a circle and accompanies the song with rhythmic blows in different parts of their body in tempo of the measure, of the melody, of both of them at the same time or in turn.

7. They sing it again by following the pace of the teacher. They repeat it as many times as necessary, so as all of them or most of them learn it.

8. Teacher and students stand up in a circle and they sing for the last time the song.

\section{Evaluation:}

Based on the following questions the teacher makes comments on the lesson:

1. Do they learn the lyrics and the melody of the song?

2. Does the song introduce them in the music of Thrace and in the rhythm of $5 / 8$ ?

3. Do they sing with enthusiasm and enjoy the experience?

4. Do they participate in the processing of the song (rhythmic blows, movement, imitation, dancing)?

5. Do they use correctly their voice?

6. Do they collaborate and they work as a team?

7. Do they link the subject and the music of the song with respective songs of their origin?

\section{Lesson Plan 2}

Topic: makeshift musical instruments and song backing.

Main activity: manufacture-singing-rhythmic backing. 
Duration: 90 minutes.

Objective:

1. To learn in Greek the names of the musical instruments and the materials from which they are manufactured.

2. Accompanying the songs that they have been taught in previous sessions in the rhythm of the measure.

Material - Means:

1. Glue, scissors, adhesive tape, hard cardboard and construction paper in various colors, recyclable materials (rolls of paper towels, boxes of cream cheese, various kinds of aluminum cans, cardboard boxes), string, rope, beads, cylindrical wood, reeds.

2. Suitable space for manufacture and movement.

Development:

1. The teacher distributes the material to the students and she explains how to manufacture a musical instrument.

2. They are divided into three workshops. In the first workshop they manufacture the kavali (Thrace). In the second workshop they manufacture a balalaika (former Soviet Union) and in the third one a heirotympano (Turkey). The teacher informs them about the countries of origin of the musical instruments and how they are manufactured. They make a link with other school subjects (Greek language, geography, environmental studies, natural sciences).

3. Students who complete their manufacture make a circle and accompany with nursery rhymes and folk songs that were taught in previous sessions to the tempo of the measure and of the melody with the help of the teacher and of the musical instruments manufactured.

4. They recite rhythmically the names of the musical instruments and the materials in Greek until they memorize them.

5. They sing all together; they move in space and play with their makeshift musical instruments.

6. They take pictures of the musical instruments and they create a board with those pictures and information on the country of origin and its culture.

Music and traditions of Thrace (Greece): a trans-cultural teaching tool 
Evaluation:

Based on the following questions the teacher makes comments on the lesson:

1. Do they learn the names of musical instruments and materials in Greek?

2. Do they participate enthusiastically in the manufacture of musical instruments and enjoy the experience?

3. Does the rhythmic recitation of the names of the materials of musical instruments help to memorize them?

4. Does the rhythmic accompaniment with their own musical instruments help them in the correct rendition of the melody and of the lyrics of the song?

5. Do they participate in the processing of the song?

6. Do they collaborate and work as a team?

7. Are they interested in information from other countries and cultures of their classmates?

\section{Epilogue-Conclusions}

Interactions among different peoples, societies or cultures in the region of Thrace are reflected in all aspects of folk art and of course, in the content of the songs. In music, it is not quite the same, because the peoples, the tribes, the nations, the societies, the minorities and the majorities, which have been participating for centuries in the multicultural setting of Thrace, may have many and different languages, habits, ways of life, beliefs or even aspirations among them, but they all share a music with the same or relative theoretical basis of which either the Byzantine or the Arabic version are uncontrollably diffused to the music act of the folk musician or singer. For centuries, they have all shared a rich music material, which is constantly changing, moving and adapting to the different needs, to the different circumstances of different traditions (Auסíkos, Е.; Папаס́́́kns, Г.; Гкоußźvта, E., 2002: 26-27).

Nobody can doubt that music is a bridge through which people from all around the world can communicate and share elements from their cultures. Prejudices and stereotypes seem to disappear whenever children have the opportunity to take part in creative and pleasant musical activities and lessons. The communication skills of students, the self-confidence and selfesteem of ethno-culturally diverse students are cultivated, while at the same time, attitudes of solidarity and empathy arise. The individual and social identity of students is reinforced, so as to 
facilitate the communication with respective experiences of the others. Their mother tongue is optimized and the second language is developed as well.

In this way, the objective of intercultural learning is accomplished: empathy, tolerance of contradictions, critical attitude rather than prejudice and stereotypes and communication-exchange. Pupils and students in this region of Greece, despite their different national backgrounds do share the land of Thrace with concord, while they are trying to eliminate the possibility of national conflicts. Music is indeed a useful communication tool, an international language for them. It helps them to integrate easier in the Greek society and to develop better relationships with Greek pupils and students and they actually prefer it, most of the times, from other school subjects or ways of integration.

\section{References}

Abril, C. (2006). Learning of two approaches to multicultural music education. International Journal of Music Education, 24, 1 (2006) 30-42.

Abril, C. (2002). Chiildren's Attitudes towards Languages and Perception of Performers' Social Status in the Context of Songs. International Journal of Music Education, 39, 1 (2002) 65-74.

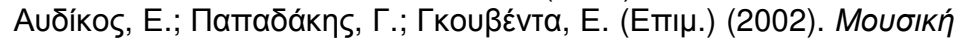

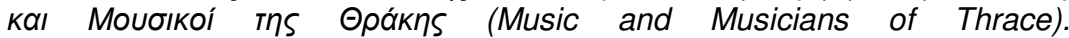

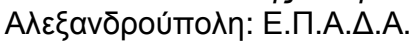

Benham, S. (2003). Being the Other Adapting to Life in a Culturally Diverse Classroom. Journal of Music Teacher Education, 13, 1 (2003) 21-32.

Burton, B. J. (2010). Multicultural Resources. General Music Today, 24, 1 (2010) 58-62.

Clements, A. (2009). Minority Students and Faculty in Higher Music Education. Music Educators Journal, 95, 3 (2009) 53-56.

Diamantis, T. (1996). Thrace in Antiquity. In N. Desyllas, Thrace, colours and hues, 22-25. Athens: Synolo.

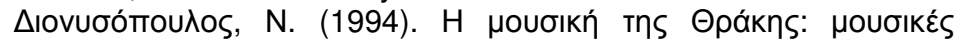

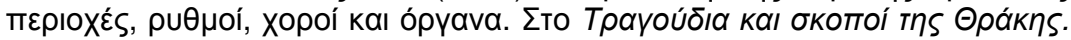

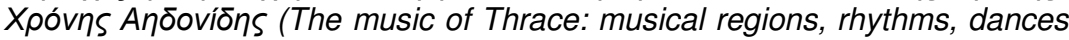
and instruments, in Songs and melodies of Thrace. Hronis Aidonidis).

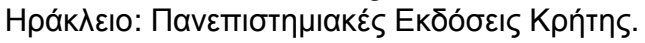

Doukas, D. (1996). The prefecture of Evros. In N. Desyllas, Thrace, colours and hues, 33-34. Athens: Synolo.

Elliott, D. (1989). Key Concepts in Multicultural Music Education. International Journal of Music Education, 13, 1 (1989) 11-18.

Legette, R. M. (2000). Social Context and Music Learning, General Music Today, 13, 3 (2000) 16-18. 
Letts, R. (1997). Music: universal language between all nations? International Journal of Music Education, 29, 1 (1997) 22-31.

Liapis, A. K. (1996). The prefecture of Rodopi. In N. Desyllas, Thrace, colours and hues, 32-33. Athens: Synolo.

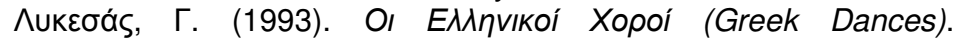

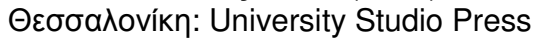

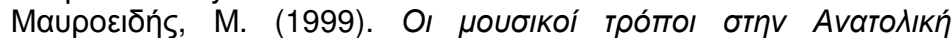

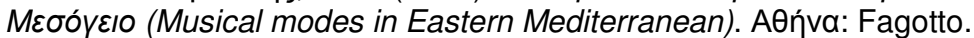

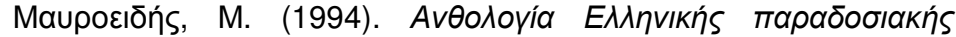

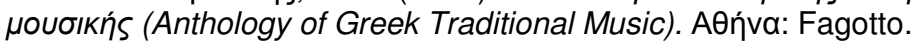

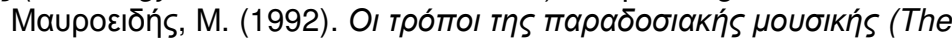
modes of traditional music). AӨńva: IEMA.

McCarthy, M. (1997). A Sociocultural approach to creativity. General Music Theory, 10, 3 (1997) 10-15.

McCrary, J. (2000). Ethnic Majority/Minority Status: Children's Interactions and Affective Responses to Music. Journal of Research in Music Education, 48, 3 (2000) 249-261.

Magno Prim, F. (1995). Tradition and change in children's games: its implication in music education. Bulletin of the Council for Research in Music Education, 127 (1995) 149-154.

Miralis, Y. (2006). Claryfying the Terms "Multicultured", "Multiethnic" and "World Music Education" through a Review of Literature. Application of Research in Music Education, 24 (2006) 54-66.

Mousopoulos, T. (1996). The turning point of the late Byzantine period and the years of Ottoman rule. In N. Desyllas, Thrace, colours and hues, 28-30. Athens: Synolo.

Mousopoulos, T. (1996). A New Era: Antitheses and Syntheses. In N. Desyllas, Thrace, colours and hues, 30-31. Athens: Synolo.

Mousopoulos, T. (1996). The prefecture of Xanthi. In N. Desyllas, Thrace, colours and hues, 31-32. Athens: Synolo.

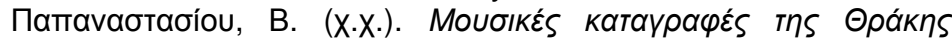
(Music transcriptions in Thrace). AӨńva: Nákas.

Palmer, A. (1994). On Cross-Cultural Music Education. Journal of Music Teacher Education, 4, 1 (1994) 19-24.

Poirazidis, K.; Samara, S. (1996). Thrace: a stroll through nature's realm. In N. Desyllas, Thrace, colours and hues, 35-37. Athens: Synolo.

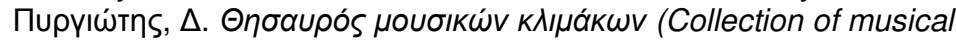
scales). AӨńva: Fagotto.

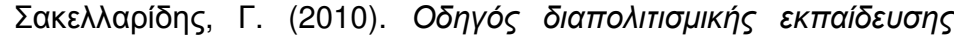
(Guide of transcultural education). AӨńva: Пєठío.

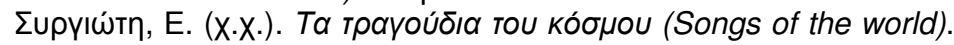
Aөńva: Fagotto.

Triantaphyllos, D. (1996). Thrace in Antiquity. In N. Desyllas, Thrace, colours and hues, 22-25. Athens: Synolo.

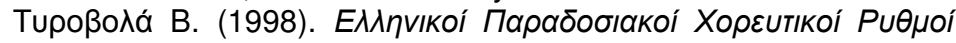
(Greek traditional dance-rhythms). AӨńva: Gutenberg.

Music and traditions of Thrace (Greece): a trans-cultural teaching tool 
Vuillamy, G.; Shepherd, J. (1984). The application of a critical sociology to music education. British Journal of music Education, 1 (1984) 247-266.

Zikos, N. (1996). A Byzantine ramble through Thrace. In N. Desyllas, Thrace, colours and hues, 25-28. Athens: Synolo.

\footnotetext{
1 Música e tradições da Trácia (Grécia): um instrumento pedagógico transcultural

${ }^{2} \mathrm{PhD}$.

College of Kea/Cyclades (Greece).

Email: kallistiga@yahoo.com

${ }^{3}$ PhD Candidate.

Democritus University of Thrace (Greece).

Email: aerikop7@otenet.gr

${ }^{4}$ See the scores in Maupozıońs (1994: 38-44, 62-63).

${ }^{5}$ See the score in $\Delta$ Iovuбómou^os (1994: 134).
} 
